\title{
THE TREND OF HEPATITIS B SURFACE ANTIGENEMIA AMONG TEACHING HOSPITAL PATIENTS IN KANO
}

\author{
"Nwokedi, E.E. ; ** Emokpae, M. A.; * Taura, A.A.; ${ }^{*}$ Dutse, A. I. \\ *Departments Of Medical Microbiology/Parasitology,Psychiatry And Medicine. Faculty Of Medicine, Bayero \\ University \& **Department Or Chemical Pathology, Aminu Kano Teaching Hospital Kano.
}

Correspondence: Dr. E. E. Nwokedi. E-mail-drnwokedi@vahoo.com

\section{ABSTRACT}

The prevalence and trend of Hepatitis B Virus infection in 2966 patients attending clinics of Aminu Kano Teaching Hospital, Kano Nigeira was determined over a 3 year period 2001 to 2003. The samples was initially screened by latex agglutination techniques while the positive samples repeated by Enzyme linked Immunosorbent Assay (ELISA) technique for confirmation. A seroprevalence of $23.3 \%$ units with coefficient variation of 22.5 to $24.1 \%$ were reported during the study period. More males $(24.1 \%)$ than females $21.5 \%$ patients were observed to be seropositive for HBsAg. The differences was not however statistically significant. The overall trend in HBsAg seropositivity over the study period showed $21.7 \%$ in $2001,24.7 \%$ in 2002 and $22.4 \%$ in 2003 respectively. Despite the availability of methods by which these viruses can be detected and surveillance activities to reduce the occurrence of the infection, the virus continues to constitute threat to health of the individuals. Our findings suggest that it is necessary to reappraise the need to intensify preventive measures in order to reduce the trend of $\mathrm{HBV}$ infections. Key Words: Hepatitis B, HbsAg, Blood, Serum, Samples

\section{INTRODUCTION}

Hepatitis $B$ virus (HBV) is one of the most important hepatotropic viruses known to be transmitted sexually, percutaneously, by blood, blood products and is known to be endemic in Africa (1\&2). Despite the availability of methods by which this virus can be detected and surveillance activities to reduce the occurrence of the infection, the virus continues to constitute a threat to the health of patients. Hepatitis B surface antigen (HBsAg) in the blood is the most useful market of active HBV infection which appears in the blood exclusive! as a component of the virus and as incomplete viral forms $(3 \& 4)$.
It has been estimated that about one third of the world's population has been infected with HBV of which over 350 millions of them are said to chronic carriers (5).

WHO estimates suggest that HBV results in two million deaths each year worldwide and 230,000 of these occuring in Africa. Even though the incidence of acute hepatitis and death as a result of it is under reported, Nigeria appears to fall within the hyperendemic region of Sub-Saharan Africa. It has been reported that upto $25 \%$ of chronic carriers of HBV develop serious liver diseases including chronic hepatitis, cirthosis and hepatocellular carcinoma (5). 
Although the prevalence of $\mathrm{HBsAg}$ has been reported among blood donors in this centre (6), information on its prevalence and trend of infection among patients is not available. Therefore, the aim of this study is to present the carriage rate and the trend of HBV infection among patients in Aminu Kano Teaching Hospital, (AKTH) Kano.

\section{METHODS}

Serum samples were collected from 2966 consecutive patients presenting to Aminu Kano Teaching Hospital (AKTH) for a period of three years from January 2001 to December 2003. They consist of 2095 males and 871 females. The age ranged from one year to 61 years. In 2001, 406 specimens were collected while 1282 and 1278 were collected in 2002 and 2003 respectively. The samples were screened for HBsAg by latex agglutination technique. All positive samples were repeated using Enzyme Linked Immunosorbent Assay (ELISA) technique (pathogyme Omega Diagnostics, UK) for confirmation.

\section{RESULTS}

Out of the 2966 patients tested over the three year period, 691 (23.1\%) were HBsAg positive. This gives a period prevalence of $23.3 \%$ with a $95 \%$ coefficient variation of $22.5 \%$ to $24.1 \%$. Of the 2095 male patients tested, 504 (24.1\%) were HBsAg positive. Similarly, out of the 871 female subjects, $187(21.5 \%)$ were positive. The differences was not statistically significant $(p=0.13)$. An examination of the overall trend of HBsAg seropositivity over the three year study period showed $21.7 \%$ in $2001,24.7 \%$ in 2002 and $22.4 \%$ in 2003 respectively. The stratification of HBsAg seropositivity by age and by sex are shown in table I and II respectively.

Table III Shows The Tread of Hepertitis B Virus Surface Antigenemia Among Teaching Hospital Patients.

\begin{tabular}{llll}
\hline Year & Total Screened & Total Pos & $\%$ \\
\hline 2001 & 406 & 88 & $(21.7)$ \\
2002 & 1282 & 317 & $(24.7)$ \\
2003 & 1278 & 286 & $(22.4)$ \\
Total & 2,966 & 691 & $(23.1)$
\end{tabular}

$\mathrm{X} 2$

$\underline{X^{2}(a)}, \mathrm{dF}$ and at $\left.P_{0.001}=13.81\right)$. Highly significant 
Table 1 shows The Distribution of Hepatitis B surface Antigenemia according to Age -Groups.

\begin{tabular}{llll}
\hline $\begin{array}{l}\text { Age Group } \\
\text { (Years) }\end{array}$ & $\begin{array}{l}\text { HBsAg } \\
\text { Positive } \\
\text { No. (\%) }\end{array}$ & $\begin{array}{l}\text { HBsAg } \\
\text { Negative } \\
\text { No. (\%) }\end{array}$ & Total No.(\%) \\
\hline$<10$ & $49(25.3)$ & $145(74.7)$ & $194(100)$ \\
$11-20$ & $93(23.5)$ & $303(76.5)$ & $396(100)$ \\
$21-30$ & $230(24.7)$ & $703(75.3)$ & $933(100)$ \\
$31-40$ & $165(22.8)$ & $559(77.2)$ & $724(100)$ \\
$41-50$ & $87(23.6)$ & $281(76.4)$ & $368(100)$ \\
$>50$ & & & $343(100)$ \\
Not stated & $8(100.0)$ & $284(82.8)$ & $8(100.0)$ \\
Total & $691(17.2)$ & & $2966(100)$
\end{tabular}

$\underline{X^{2} @ 1 d F}$ and at $P_{0.001}=(13.81)$.Highly significant

Table II shows The Gender Distribution of Hepatitis B surface Antigenemia among Teaching Hospital patients in Kano.

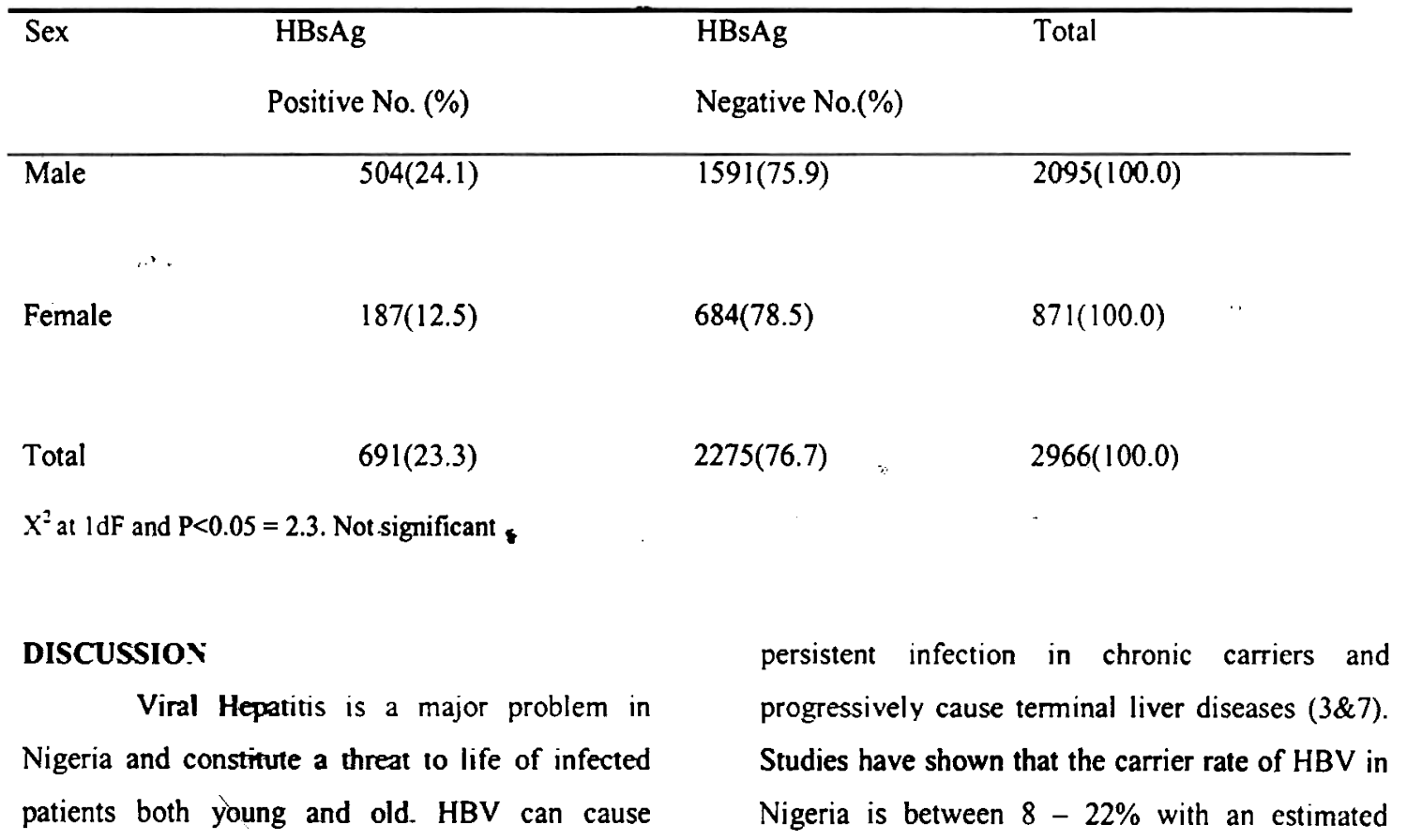


exposure rate of above $60 \%(8,9 \& 10)$. This is consistent with this study, which showed a prevalence rate of $23.1 \%$ over a 3 -year period. This relatively stable rate may reflect the adequacy of blood transfusion services with respect to screening for HBV infection in blood donors (3).

Although the seroprevalence rate observed in this study is consistent with other studies in Nigeria, it is however higher than $10 \%$ found in Pakistan (11\&12) and $5 \%$ in India (13). But when compared with the rate observed in other African countries, the seroprevalence rate observed in this study is lower than $79 \%$ reponted in Ethiopia. $56.2 \%$ in Kenya and $792 \%$ in Mozambique (5). Among the various viral Hepatitis, the $\mathrm{HBV}$ is more distribured and spreading at the rate which is higher than HIV within the individua!s (13). Scruprevalenec ratc of HBV has been reparted in paticmis with different ailments in Nigera such as Sickle Cell discasc (14), Acute Icteric Hedetrus (15). Diabctes Mellitus (16) and HepatoCellelar Carcinoma (17). The prevalence in these various disease conditions are not different from that observed in the generzte population except for HepatoCeltular Cectnoma and Acute Icteric Hepatitis.

There was no significant difference in the prevalence rate of infection in the various age groups except for those in the age of above 50 years. This may be due to the small number of patients in this age group (Table 1).

Conversely, the seropositivity in the males were higher than in the females patients (Table 1). This is also consistent with other authors ${ }^{5}$ who reported a higher carriage rate of $77 \%$ in males than $50 \%$ in females in South Africa. The trend of infection within the study period is statistically significant $(\mathrm{P}<0.001)$.

In Africa, transmission of $\mathrm{HBV}$ is usually horizontal in childhood. The prevalence of HBV among pregnant women is said to be much lower than in Chinese women and so vertical transmission is less important.

Some risk factors identified among the study subjects include previous blood transfusion, traditional surgery, scarification, occupational exposure and exposure to infected sex partners. Social status appears to have no effect in carriage of HBV in this study population.

It is necessary to rcappraise mcasures of prevention of HBV infection in order to reduce the trend of infection. Emphasis should be placed on immunization of those at risk, avoidance of sharp objects and contaminated infection, vigorous screcning of all blood and blood products to be transfused, practice of safer scx, good personal hygienc and health workers must use the Universal Precaution for protection.

\section{REFERENCES}

1. Ayools, E. A Viral hepatitis in Africa is the 90s: facing realities. Viral hepatitis and liver discases. 1994; $381-384$.

2. Kire, C. F. Hepatitis B Infection in Sub Saharan African. The African Regional Sudy group. Vaccine. 1990, 8:107-112.

¿. Faso'a F. A. Odaibo G. N, Aken'Ova Y.A an O'a!eve. O. D. Hepatitis B and C Viz! makers in parients with Sickle Cell disease in Bedan. Nigetia. Afri. J. Med. Sci. 2003, 32: $293-295$.

4. Bayer, M. R, Blumberg BS and Weiner B. Particles associatod with Australias antigen is the sera of patiepts with Leukaemia, Down Syndrome and Hepatitis.

5. Malu, A.O. Viral Hepatitis B: Time for action in Nigeria. Med,-Link. J. 2003; $4(4)$ : $10-12$. 
6. Takalmawa, H.U., Emokpae, $M, A$, Abubakar A, G, and Kwaru A, $H$. Prevalence of Hepatitis B, surface Antigen and Human Immunodeficiency Virus antibodies among blood donors in Aminu Kano Teaching Hospital, Kano - Nigeria, 1996 - 2001, Hamdaw Med, 2004; XLVII, 2; 54 - 57 ,

7. Aken'Ova, Y, A, Olasode, B, J, and Ogunbiyi, J, O, Thomas, J. 0 Hepatobilliary changes in Mgenawis with Sickle Cell anaemia. Annals of Trop. Med. and Parasiology 1993; 87; (6): 603 606,

8, Olaleye, O, O, Ekweozor C, $C$ and Meyer. C. Hepatitis B surface antigen in patients attending the sexually transmitted disease clinic in Ibadan, Nigeria, Afri. J, Med, Sci. 1996; 25; $117-121$.

9, Harry T, O. Bajani M D and Moses A. E Hepatitis $B$ virus infection among blood donors and pregnent women in Maiduguri, Nigeria East Afr. Med, J. 1994; 71 (9): 596 - 597 ,

10. Bojuwoye B. J. The burden of Viral Hepatitis in Africa. West Afr. J. Med. 1997 ; 16(4): $198-203$.

11. Sanjrani, M, A Hepatitis B; Causes Preventions and treatment - Health Magazine, Daily Awani Awaz, Karachi 1997:5,
12. Editorial, control of Hepatitis B; need for Univercal Immunization. Quart, Med. channel, Karachi 1996:5.

13. Dharejo, A, M. Liver eating Virus - In Health Magazine, Daily Awani Awaz Karachi 1998:5.

14, Haliru, N. K, Ajayi, O. I. Risk factors and seroprevalence of hepatitis $\mathrm{C}$ antibody in blood donors in Nigeria. East Afr. Med. J, $2000 ; 77(8) ; 410-412$.

15. Ola, \$. O, Otegbayo, J. A Odaibo O. W, Olaleye 0,0, Olubuyide, 0 . L, Senu Hepatitis C virus and Hepatitis B surface antigenaeruis in Nigerian patients with acute Icterie Hepatitis West. Afr. J. Med. 2002; 21(3); $215-217$

16, Onyekwere C. A, Anómneze E. E, Wali 3.S, Prevalence of serological markers of chronic Hepatitis B Virus infection in diabetics in the Lagos University Teaching Hospital, Lagos. Nig. Postgrad. Med.J. 2002; 9(3):129 - 133.

17. Olubuyide, I, O., Aliyu B., Olaleye, O. A, Ola, 8. O., Olawuyi, F., Malabu, U.H., Odemuyiwa, S. O., Odaibo, G. N., Cook, G. C. Hepatitis B and C Virus and Hepatocellular Carcuridma. Trans. R, Boc, Trop. Med. Hyg. 1997; 91(4): 491 - 492. 